\title{
Presenting a conceptual model to explain the role of strategic management and planning in Islamic banking competitiveness
}

\author{
Seyed Reza Seyed-Javadin, Reza Raei, Mohammad Javad Iravani, \\ Mohammad Safari* \\ ${ }^{1}$ Faculty of Management, University of Tehran, Tehran, Iran \\ *E-mail address: m.safari@ut.ac.ir
}

\begin{abstract}
Financial system is the heart of any economy. To superior performance in the national and local level it is essential to have an efficient and convenient banking system. What this study aimed to discuss is that strategic management principles, content and benefits should be considered in order to achieve a higher successfulness in the Islamic banking planning, implementation and control. In today financial services market lack of strategic and long term visions and planning is one of the challenges and problems related to the Islamic banking. Thus this paper aimed at present the theoretical framework to illustrate the key role of strategic management and planning in the Islamic banking successful management and implementation. In order to present the framework this study using qualitative method, based on the detailed literature review and previous researches according to the identified models of both strategic management and competitive advantage final theoretical model has been provided. Strategic management with its unique features is primary designed to help the organization operate successfully in dynamic, complex environment especially in the financial and banking markets. Strategic management links the basic elements of an organization so integrated that breakthrough in turbulent business environment can be achieved.
\end{abstract}

Keywords: Islamic banking; strategic management; competitive advantage; competitiveness

JEL Classification: G21, M1, M21, N25

\section{INTRODUCTION}

Financial system is the heart of any economy. To superior performance in the national and local level it is essential to have an efficient and convenient banking system. What this study aimed to discuss is that strategic management principles, content and benefits should be considered in order to achieve a higher successfulness in the Islamic banking planning, implementation and control. Lack of strategic and long term visions and planning is one of the challenges and problems related to the Islamic banking today. Islamic banking has the same purpose as conventional banking: to make money for the banking institute by lending out capital. But that is not the sole purpose either. Adherence to Islamic law and ensuring fair play is also at the core of Islamic banking. Because Islam forbids simply lending out money at interest, Islamic rules on transactions have been created to prevent it. The basic principle of Islamic banking is based on risk-sharing which is a component of trade rather than risk-transfer 
which is seen in conventional banking. Islamic banking introduces concepts such as profit sharing, safekeeping, joint venture, cost plus, and leasing. The Islamic banking is one of the most rapidly emerging trends in many different parts of the world. The interest based banking system has now been very evident to the economies regarding their impacts on the economies and the individuals involved (Asif \& Anjum, 2012).

The Islamic banking system is based on the pricing of goods and services instead of the pricing of money in these economies. The Islamic banking system follows the principal provided by the Islamic Shariah (Asif \& Anjum, 2012). This principal provided by the Islamic Shariah prohibits interest in the money transaction in the Islamic economies and forbids the pricing of money in these economies. The Islamic banking system follows the principal of Islamic Shariah as provided by the Holy Quran and implement theses principals in their transaction and their transaction to make them free of Riba (Gait \& Worthington, 2007). The Islamic economic system prohibits interest and all the transactions which involve interest in order to remove the drawbacks of the interest based banking from the Islamic economic system (Asif \& Anjum, 2012). Therefore, the main purpose of this study is to present a theoretical framework that illustrated the key role of strategic thinking and management in creating a sustained competitive advantage in the Islamic banking sector in the today's economic context.

\section{STRATEGIC MANAGEMENT AND COMPETITIVENESS}

Strategy is defined as the determination of the basic long-term goals of an enterprise, and the adoption of courses of action and the allocation of resources necessary for carrying out these goals (Chandler, 1962). Indeed, Strategies are established to set direction, focus effort, define or clarify the organization, and provide consistency or guidance in response to the environment (Mintzberg, 1987). Strategic management is the set of managerial decision and action that determines the long-run performance of a corporation. It includes environmental scanning (both external and internal), strategy formulation (strategic or long range planning), strategy implementation, and evaluation and control. The study of strategic management therefore emphasizes the monitoring and evaluating of external opportunities and threats in lights of a corporation's strengths and weaknesses (Hunger \& Wheelen, 2007).

Hunger and Wheelen (2007) believe that Strategic management has now evolved to the point that it is primary value is to help the organization operate successfully in dynamic, complex environment. To be competitive in dynamic environment, corporations have to become less bureaucratic and more flexible. In stable environments such as those that have existed in the past, a competitive strategy simply involved defining a competitive position and then defending it. Because it takes less and less time for one product or technology to replace another, companies are finding that there are no such thing as competitive advantage. Strategic management involves the formulation and implementation of the major goals and initiatives taken by a company's top management on behalf of owners, based on consideration of resources and an assessment of the internal and external environments in which the organization competes (Nag et al, 2007).

Strategic management provides overall direction to the enterprise and involves specifying the organization's objectives, developing policies and plans designed to achieve these objectives, and then allocating resources to implement the plans. Academics and practicing managers have developed numerous models and frameworks to assist in strategic decision making in the context of complex environments and competitive dynamics (Ghemawat, 2002). Michael Porter identifies three principles underlying strategy: creating a "unique and valuable 
[market] position", making trade-offs by choosing "what not to do", and creating "fit" by aligning company activities to with one another to support the chosen strategy (Porter, 1996). Strategic management consists of different tasks to successful strategy work. Figure 1 shows five basic tasks of strategic management.

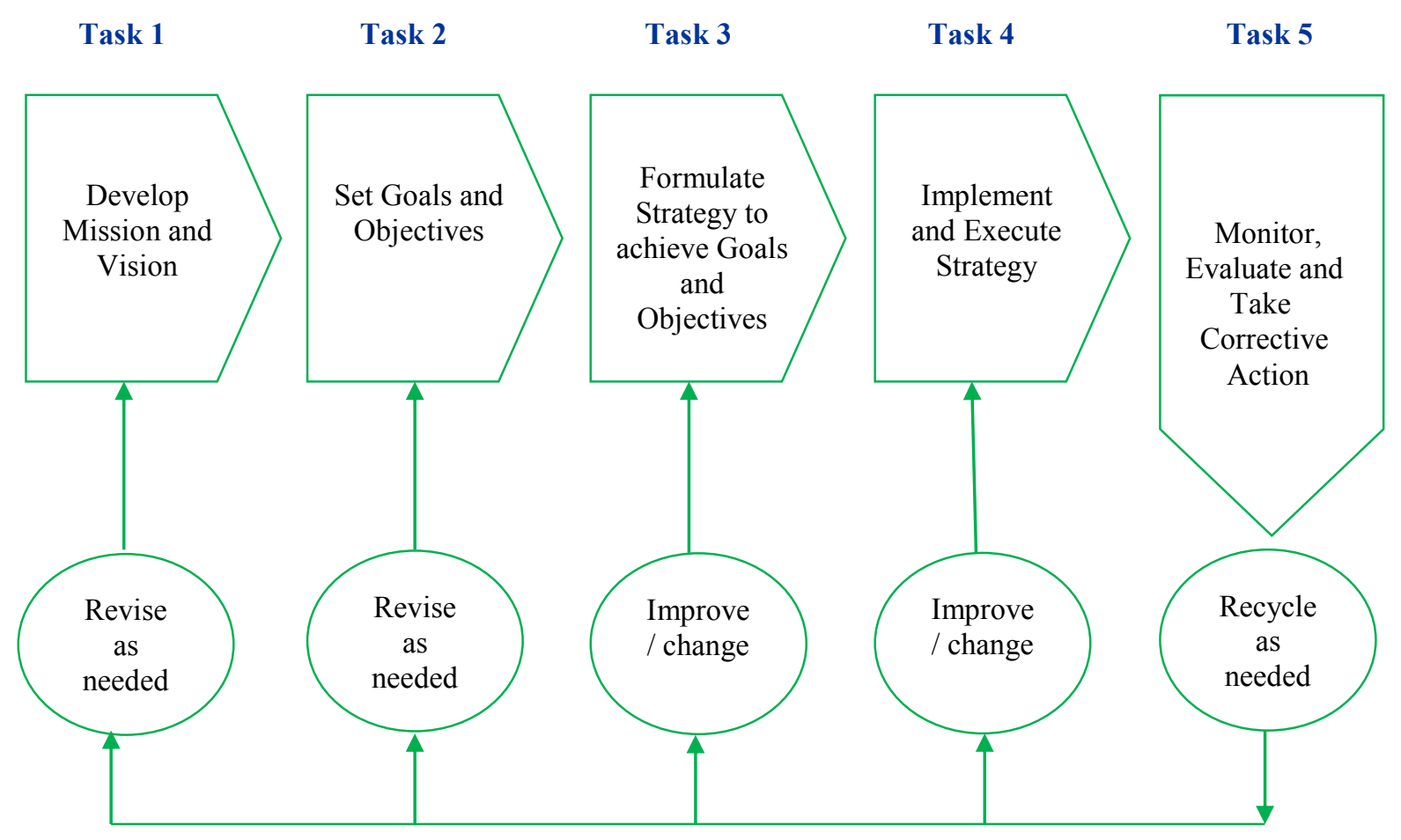

Figure 1. The five tasks of strategic management (Adapted from: Peng Chan)

The fundamental question in the field of strategic management is how firms achieve and sustain competitive advantage (Teece et al, 1997). Competitive advantage occurs when an organization acquires or develops an attribute or combination of attributes that allows it to outperform its competitors. These attributes can include access to natural resources, such as high grade ores or inexpensive power, or access to highly trained and skilled personnel human resources. New technologies such as robotics and information technology can provide competitive advantage, whether as a part of the product itself, as an advantage to the making of the product, or as a competitive aid in the business process. Michael Porter defined the two types of competitive advantage an organization can achieve relative to its rivals: lower cost or differentiation. This advantage derives from attribute(s) that allow an organization to outperform its competition, such as superior market position, skills, or resources. In Porter's view, strategic management should be concerned with building and sustaining competitive advantage (Porter, 1985).

Hao Ma (1999) in a study entitled: "Constellation of competitive advantage: components and dynamics" argues that to achieve persistent superior performance, a firm needs competitive advantages, a constellation of them. Superior firms typically do not do just one thing well; they often excel in multiple aspects. Nurturing an evolving constellation of multiple advantages and undertaking timely renewals help carry the firm through competition over time. To maintain healthy dynamics of a firm's constellation of advantage, the following tasks should be carefully 
attended to: establishment of dominant advantage which defines the firm's core purpose and identity; accumulation of supporting advantages to complete the constellation; amplification of complementary advantages for maximum performance; trade-off among competing advantages for long-term viability; and renewal of both dominant and supporting advantages, in adaptation to changes in the firm, competition, and the general environment. Knowledge of the relationship between and interaction of multiple advantages is essential for managing a firm's advantage constellation, a critical challenge facing general managers (Ma, 1999a). Figure 2 shows the results of his research well.

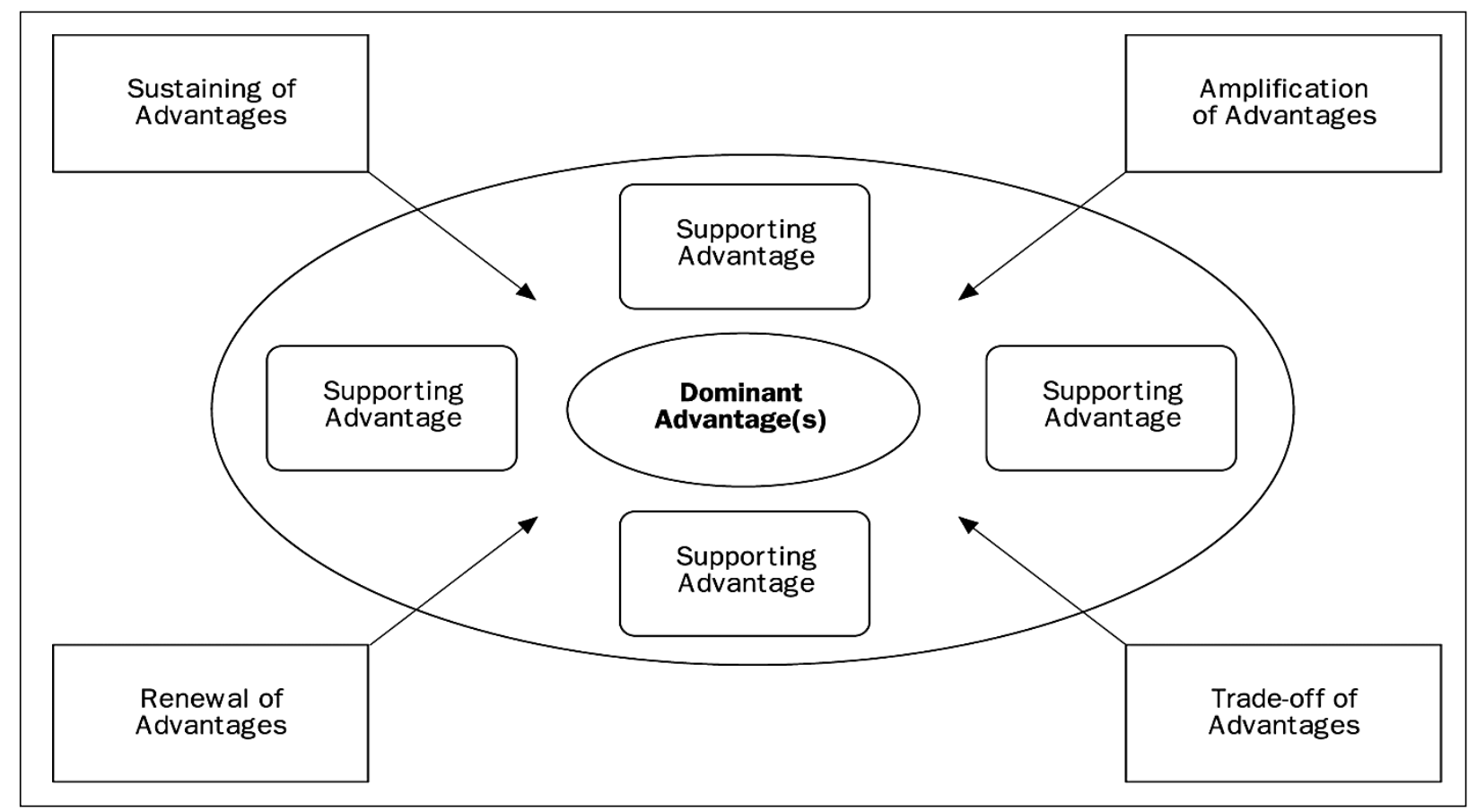

Figure 2. Dimensions of competitive advantage (Adapted from: Hao Ma, 1999a).

Also, Hao Ma (1999b) in a study entitled: "Anatomy of competitive advantage: a SELECT framework" stated that understanding the anatomy of competitive advantage is of paramount importance to general managers who bear the ultimate responsibility for a firm's long term survival and success.

Advances an integrative framework called SELECT to help general managers systematically examine the various facets of the anatomy of competitive advantage: its substance, expression, locale, effect, cause, and time-span. Analyzing the causes of competitive advantage helps a firm create and gain advantage. Studying the substance, expression, locale, and effect of competitive advantage allows the firm to better utilize the advantage.

Examining the time span of competitive advantage enables the firm to fully exploit the advantage according to its potential and sustainability. His finding about the competitive advantage is illustrated in the Figure 3. 


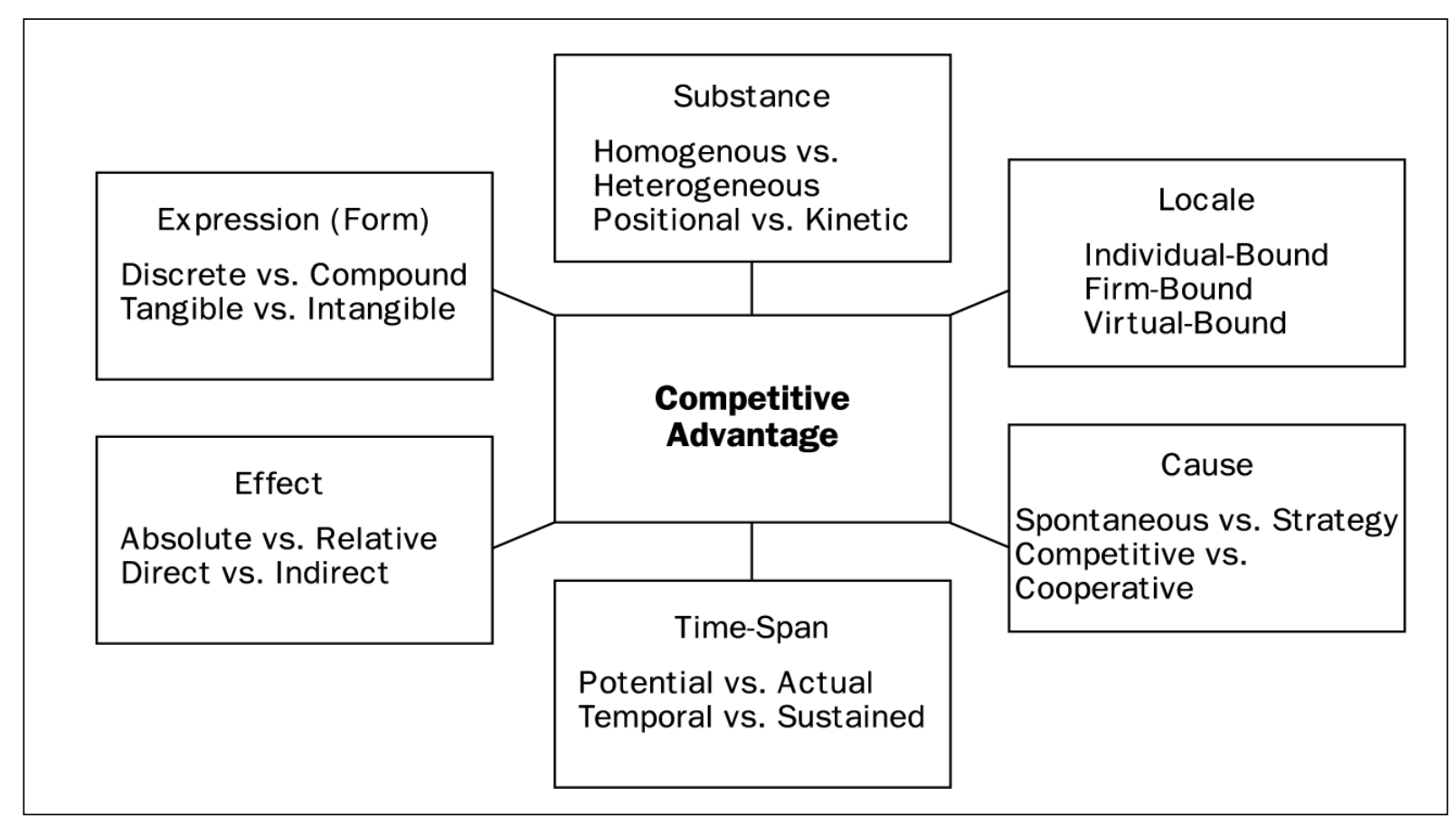

Figure 3. Anatomy and perspectives of competitive advantage (Adapted from: Hao Ma, 1999b).

\section{ISLAMIC BANKING}

The theory of Islamic banking is based on the concept that interest is strictly forbidden in Islam, and that Islamic teachings provide the required guidance on which to base the working of banks. The basic principle that has guided all theoretical work on Islamic banking is that although interest is forbidden in Islam, trade and profit is encouraged (Gudarzi-Farahani \& Sadr, 2012).

The most important mission of Islamic banks refers to establishing developed social and economic environment through the distribution of financial product and services that is in line with principle of Islam and Shariah (Metawa and Almossawi, 1998).

These products and services should be presented to society and simultaneously be used by different clusters of customers. Since this banking system is stable in its nature, it would be able to improve economic growth of the countries that use this banking method (Jamshidi and Hussin, 2013 In Jamshidi et al, 2014).

While the opportunities for Islamic banking will continue to grow, there is a need to develop products and services that are in line with the changing needs and demands of customers to remain competitive in the business (Thambiah et al, 2011).

The introduction and development of Islamic banking systems is highly competitive not only in Islamic countries, but among non-Muslim countries as well (Abdul-Hamid, 2011).

The Islamic banking advocators argued that Islamic method of banking as well as financing unlike conventional ones is fundamentally secure in its nature and therefore do not provide economic crash (Shayegani and Arani, 2012). In the following some of related researches and studies have been mentioned. 
The basic principle in Islamic law is that exploitative contracts or unfair contracts that involve risk or speculation are impermissible.

Under Islamic banking, all partners involved in financial transactions share the risk and profit or loss of a venture and no one gets a predetermined return. This direct correlation between investment and profit is the key difference between Islamic and conventional banking which its main objective is maximizing shareholders' wealth (Dar and Presley, 2000 In Gudarzi-Farahani \& Sadr, 2012).

Islamic banking activities can be classified into two groups: In one group, their activities are without any competition with conventional banking based on interest rate, due to the domestic laws and regulations of some Islamic countries which do not allow any activities based on interest rate (ribah) for financial institutions, banks in those countries.

In the second group, there is a high competition between these two banking systems which is because of this fact that they are operating in non-Muslim countries or Muslim countries which do not forbid interest rate-based banking system (Gudarzi-Farahani and Dastan, 2013).

Banking system and activities have a special and crucial status in Iran. Indeed, banking sector is the biggest body of Iranian service sector of economy (Safari \& Safari, 2012). SeyedJavadin et al (2014) in a research identified and prioritized the important challenges regarding to the Islamic banking system in I.R. Iran (Seyed-Javadin et al, 2014).

Karbhari et al (2004) investigated the main problems, challenges, and opportunities facing Islamic banking system especially with focus on the United Kingdom. Estiri et al (2011) identified and extend the conceptualization and measurement of customer satisfaction in the Islamic banking sector in Iran.

Jamshid and Hussin (2012) proposed a conceptual framework to explore factors that affect Islamic credit card adoption and usage by bank customers in Malaysia. Rammal and Zurbruegg (2014) examined the awareness of Muslim Australians of Islamic banking, particularly profit-and-loss sharing agreements.

\section{METHOD}

This research is designed based on the qualitative method. Using detailed literature review and research background the proposed model has been presented. Then by means of deep interviews with experts of the current research field, required data to evaluate the research model has been gathered and then analyzed.

Qualitative research is a useful method that helps researchers to deep studies related of the socities and provides better insights for decisions. Qualitative research is a method of inquiry employed in many different academic disciplines, traditionally in the social sciences, but also in market research and further contexts (Denzin \& Lincoln, 2005).

Qualitative researchers aim to gather an in-depth understanding of human behavior and the reasons that govern such behavior.

The qualitative method investigates the why and how of decision making, not just what, where, when. Hence, smaller but focused samples are more often used than large samples.

Accordingly, the sample of this research was including 20 experts of the field of study that has commented about the model. 


\section{RESEARCH MODEL}

In this section the research theoretical model has been presented. This model is a combination of the key components of competitive advantage and strategic management approach.

This is a map that contributes to both academicians and practitioners of the field of study. Also Figure 5 shows the status of model's elements that all have a high position.

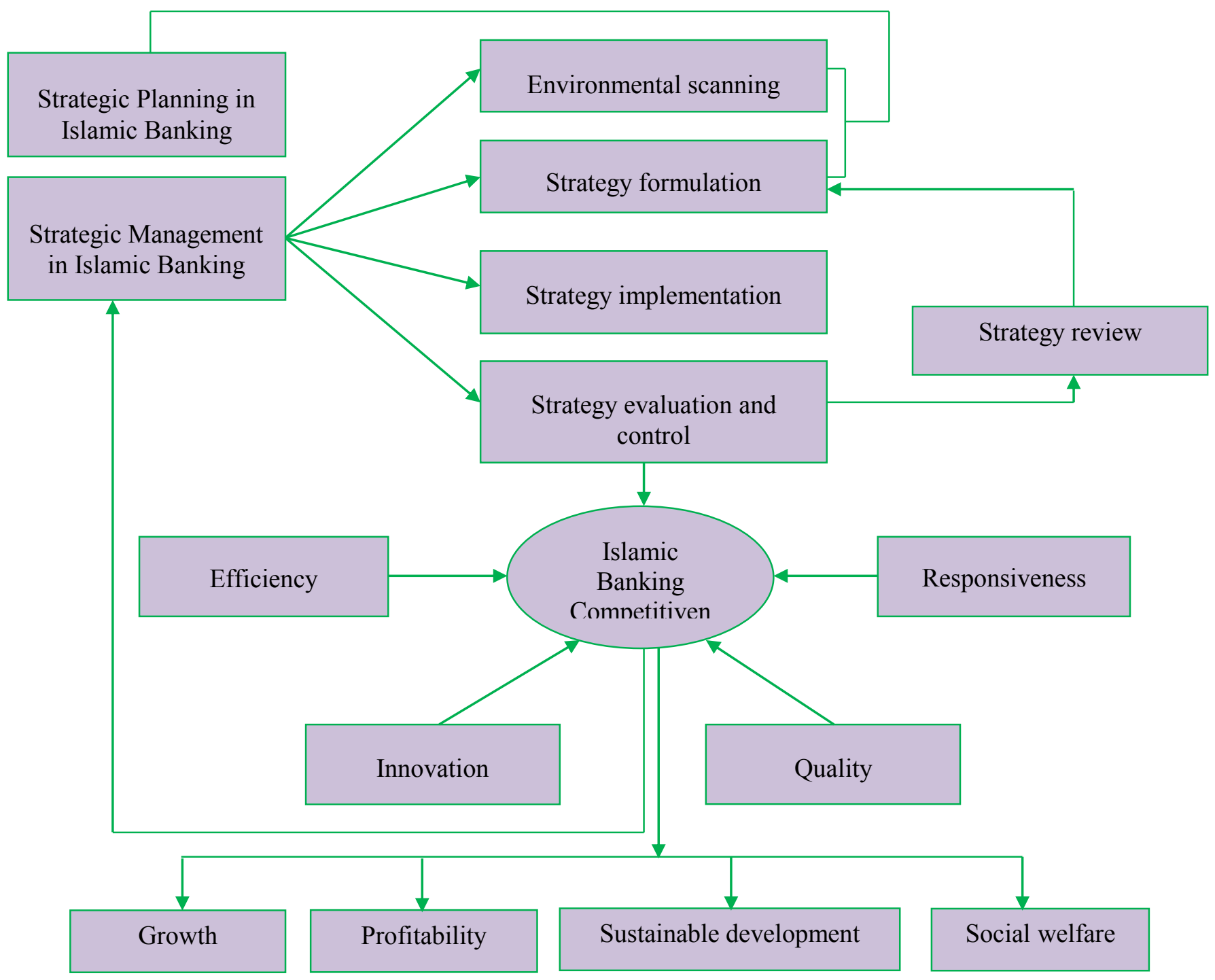

Figure 4. The theoretical research model. 


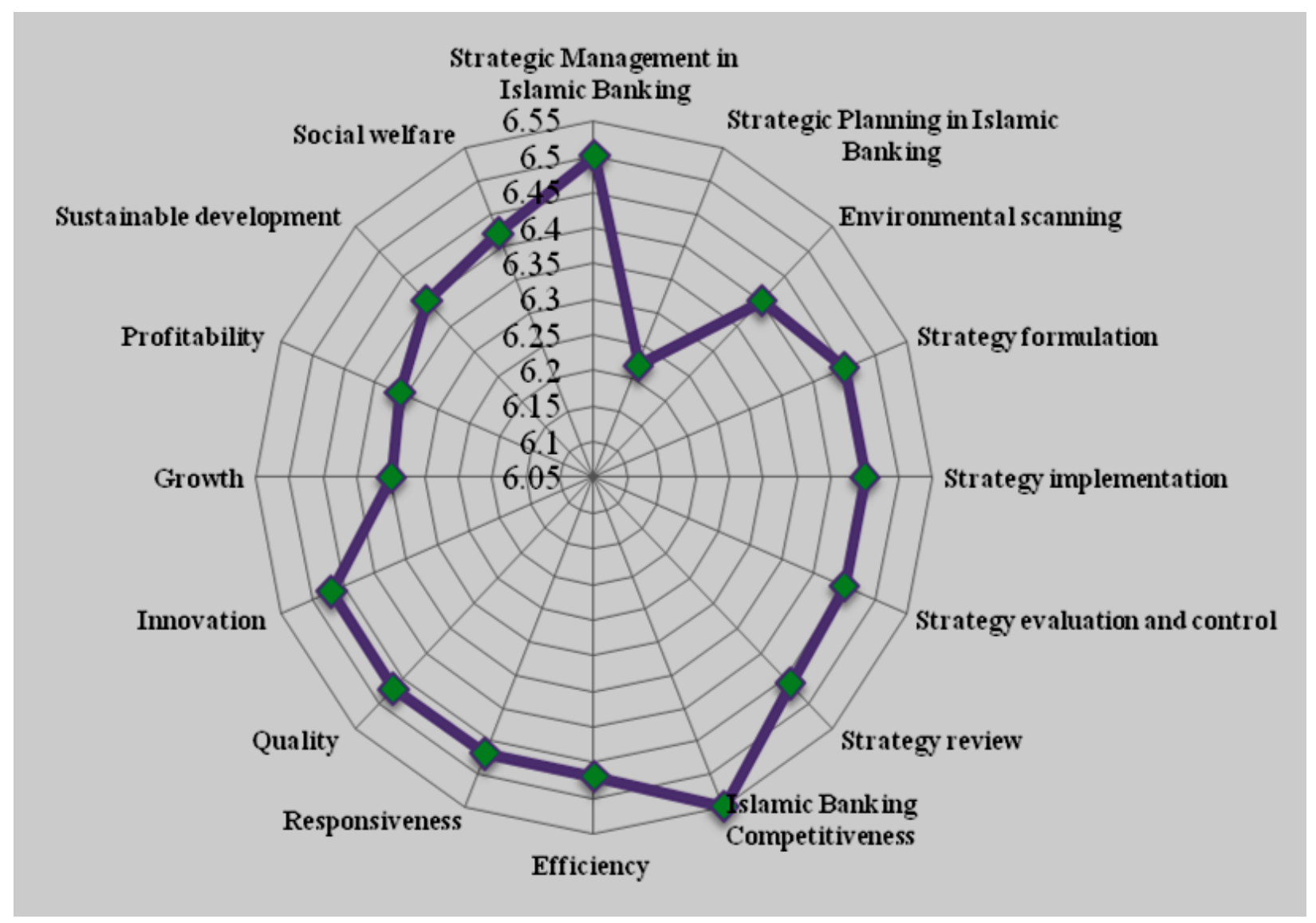

Figure 5. Results f data analysis for the status of proposed model's elements.

\section{DISCUSSION AND CONCLUSION}

Having the strategic thinking can lead to the creation of differentiation, superiority and excellence in the today business market. In the modern economy, competitiveness means information and know-how rather than capital and physical assets. Therefore, the key process for any competitive organization is to strategically use their information resources and knowledge assets by remembering and applying experience (Nedelea \& Paun, 2009). This study investigated this important issue for the economic and banking sector. In Islamic economics as a significant and considerable part of world's economy, Islamic banking can play a major role in balancing the financial system and consequently to prosperity of the Islamic economies. For achieve success of Islamic banking system in the economics the strategic thinking, planning and management are the key.

This study presents a theoretical model to link and integrate the basic elements of strategic management, competitive advantage and Islamic banking implementation resulting from previous studies review and some interview. Accordingly, appropriate execution of strategic management will leads to create a sustained competitive advantage in the banking and financial services especially Islamic banking sector in the economics. Strategic management is critical to the development and expansion of banking services and activities, as it aligns the mission and vision with operations. An organization's ability to compete on the market is increasingly seen as depending on the skills and knowledge of its managers and employees, regarded as intellectual capital, and put to good use while formulating, implementing and adjusting 
strategies (Nedelea \& Paun, 2009). Hence achieving the competitiveness in the turbulent economics environment is based on the best utilizing the limited resources to response to the market demands and wants. This will be possible when the four basic elements or parameters well created; these parameters are innovation, quality, efficiency and responsiveness. When these four items are integrated and working well, then we obtain a sustainable competitive advantage. Once a sustainable competitive advantage is obtained, then the basic goals and objectives are available. In the other words, the Islamic banking system and Islamic economics can achieve to growth, profitability, sustainable development, and social welfare successfully.

\section{References}

[1] Abdul-Hamid M., Azmi S. M. (2011). The performance of banking during 2000-2009: bank Islam Malaysia Berhad and conventional banking in Malaysia. International Journal of Economics and Management Sciences, 1(1); 09-19.

[2] Asif M., Anjum M. A. (2012). Acceptance of Islamic Banking in Muslim Customers a Comparative Study on Flaws of Interest Based Banking vs Positive Aspects of Islamic Banking. International Review of Management and Business Research, 1(1); 9-17.

[3] Chandler A. (1962). Strategy and Structure: Chapters in the history of industrial enterprise. Doubleday, New York.

[4] Dar H.A., Presley J.R. (2000). Lack of profit loss sharing in Islamic banking: management and control imbalances. International journal of Islamic financial services, 2(2), 1-16.

[5] Denzin N. K., Lincoln Y. S. (Eds.). (2005). The Sage Handbook of Qualitative Research (3rd Ed.). Thousand Oaks, CA: Sage.

[6] Estiri M., Hosseini F., Yazdani H. (2011). Determinants of customer satisfaction in Islamic banking: evidence from Iran. International Journal of Islamic and Middle Eastern Finance and Management, 4(4); 295-307.

[7] Gait A., Worthington A. (2007). An Empirical Survey of Individual Consumer, Business Firms and Financial Institution Attitude towards Islamic Methods of Finance. Working Paper Series at University of Wollongong, School of Accounting and Finance, No. 07/08.

[8] Ghemawat P. (2002). Competition and business strategy in historical perspective. Business history review, working paper retrieved from the Social Science Research Network electronic library at: http://papers.ssrn.com/paper.taf?abstract_id=264528.

[9] Gudarzi-Farahani, Y. \& Dastan, S.M. (2013). Analysis of Islamic bank's financing and economic growth: A panel cointegration approach. International Journal of Islamic and Middle Eastern Finance and Management, 6(2); 156-172.

[10] Gudarzi-Farahani Y., Sadr S.M.H. (2012). Analysis of Islamic Bank's Financing and Economic Growth: Case Study Iran and Indonesia. Journal of Economic Cooperation and Development, 33(4); 1-24.

[11] Hunger D., Wheelen T. L. (2007). Essentials of Strategic Management (4 $^{\text {th }}$ Ed.). Upper Saddle River, NJ: Pearson Education.

[12] Jamshidi D., Hussin N. (2012). A conceptual framework for adoption of Islamic Credit Card in Malaysia. Kuwait Chapter of Arabian Journal of Business and Management Review, 2(3); 102-110. 
[13] Jamshidi D., Hussin N. (2013). Determining a Conceptual Framework for Adoption of Islamic Credit Card in Context of Malaysia. Journal of Basic and Applied Scientific Research, 3(1); 188-196.

[14] Jamshidi D., Hashemi K., Hussin N., Wan H. L., Mossafa S. (2014). Investigating critical factors influencing acceptance and marketing strategies of Islamic banking services in Malaysia. International Journal of Accounting Research, 1(10); 41-49.

[15] Karbhari Y., Naser K., Shahin Z. (2004). Problems and Challenges Facing the Islamic Banking System in the West: The Case of the UK. Thunderbird International Business Review, 46(5); 521-543.

[16] Ma H. (1999a). Constellation of competitive advantage: components and dynamics. Management Decision, 37(4); 348-356.

[17] Ma H. (1999b). Anatomy of competitive advantage: a SELECT framework. Management Decision, 37(9); 709-718.

[18] Metawa S. A., Almossawi M. (1998). Banking behaviour of Islamic bank customers: perspectives and implications. International Journal of Bank Marketing, 16(7); 299-313.

[19] Mintzberg H. (1987). Why Organizations Need Strategy. California Management Review, 30(1); 25-32.

[20] Nag, R.; Hambrick, D. C. \& Chen, M. (2007). What is strategic management, really? Inductive derivation of a consensus definition of the field. Strategic Management Journal, 28(9), 935-955.

[21] Nedelea S., Paun L. A. (2009). The Importance of the Strategic Management Process in the Knowledge-Based Economy. Review of International Comparative Management, 10(1); 95-105.

[22] Porter M. E. (1985). Competitive Advantage. The Free Press.

[23] Porter M. E. (1996). What is Strategy?. Harvard Business Review, 74 (6); 61-78.

[24] Rammal H. G., Zurbruegg R. (2006). Awareness of Islamic banking products among Muslims: The case of Australia. Journal of Financial Services Marketing, 12(1); 65-74.

[25] Safari-Kahreh M., Safari-Kahreh Z. (2012). An Empirical Analysis to Design Enhanced Customer Lifetime Value Based on Customer Loyalty: Evidences from Iranian Banking Sector. Iranian Journal of Management Studies, 5(2); 145-167.

[26] Safari-Kahreh M., Ahmadi H., Hashemi A. (2011). Achieving competitive advantage through empowering employees: An empirical study. Far East Journal of Psychology and Business, 3(3); 26-37.

[27] Safari-Kahreh M., Tive M., Babania A., Hesan M. (2014). Analyzing the Applications of Customer Lifetime Value (CLV) based on Benefit Segmentation for the Banking Sector. Procedia-Social and Behavioral Sciences, 109; 590-594.

[28] Safari-Kahreh M., Tive M., Babania A., Hesan M. (2014). Analyzing the Applications of Customer Lifetime Value (CLV) based on Benefit Segmentation for the Banking Sector. Procedia-Social and Behavioral Sciences, 109; 590-594. 
[29] Seyed-Javadin S. R., Raei R., Iravani M. J., Safari M. (2014). An explanatory analysis to identify and prioritize the challenges of Islamic Banking implementation: the case of IR Iran. International Letters of Social and Humanistic Sciences, 24; 45-55.

[30] Shayegani B., Arani M. A. (2012). A Study on the Instability of Banking Sector in Iran Economy. Australian Journal of Basic and Applied Sciences, 6; 213-221.

[31] Teece D. J., Pisano G., Shuen A. (1997). Dynamic capabilities and strategic management. Strategic Management Journal, 18(7); 509-533.

[32] Thambiah S., Ismail H., Malarvizhi C. A. (2011). Islamic Retail Banking Adoption: A Conceptual Framework. Australian Journal of Basic and Applied Sciences, 5(12); 649657. 